\title{
CIVIL DEFENSE SYSTEM IN LATVIA AND IDENTIFIED DRAWBACKS IN RIGA
}

Mihails URBANS, Institute of Labour Safety and Civil Defence at Riga Technical University, Faculty of Engineering Economics an Management, 6 Kalnciema Str., Riga, LV-1658, Latvia; mihails.urbans@ riga.lv (corresponding author)

Jeḷena MALAHOVA, Institute of Labour Safety and Civil Defence at Riga Technical University, Faculty of Engineering Economics an Management, 6 Kalnciema Str., Riga, LV-1658, Latvia; jelena.rtu@inbox.lv

Jānis IEVIN̦ŠS, Institute of Labour Safety and Civil Defence at Riga Technical University, Faculty of Engineering Economics an Management, 6 Kalnciema Str., Riga, LV-1658, Latvia; janis.ievins@ @rtu.lv

\begin{abstract}
The article considers Latvian Civil Defence System (hereinafter referred to as CD), how it works in cases of possible threats, how CS system protects the safety of people and national economy as well as the interests of the entire society in case of a catastrophe; types of CD system safety measures, provision thereof, what processes affect CD system in Riga; attitude of responsible state institutions towards national safety system and environment. Based on the abovementioned, we will review how the society itself has influenced its own safety and based on its outcome we will see what protection measures should be provided from the standpoint of safe human and social life, why the drawbacks, deficiencies and indifferent attitude are allowed in relation to the safety system processes in the country and Riga. In the aspect of CD regulatory enactments methodology, an attempt is made to explain the current drawbacks in safety processes of tasks to be fulfilled by the municipality by means of calculations thus identifying the reasons that all emergency situations, breakdowns, catastrophes resulting from technogenic and natural risks depend on the attitude of state institutions, local governments and the society towards the safety, and on general economic situation.
\end{abstract}

Keywords: high hazard objects, environment protection, civil defence, disasters.

\section{INTRODUCTION}

Human impact on environment is as old as the mankind itself. Already since ancient times people affect environment wherein they live and when local resources are exhausted people move over to elsewhere looking for better and cozier life. In our times, people affect the environment not only in the short run but also globally and durably. Where the nature is unaffected by people, the exchange of substances proceeds completely enough (Krūzs..., 2003). Human consumption of world resources is constantly increasing with each passing year, together with growth in world population, thus increasing the impact on the environment, and it involves the extraction, transportation and disposal of raw materials, resulting in the setting of new and up-to-date requirements for the $\mathrm{CD}$ system in relation to protection and safety of inhabitants and production facilities against technogenic and environmental effects. On November 21, 2013 Maxima shopping center's roof collapsed in Riga, Latvia causing 54 deaths and creating international news. The collapse of the supermarket in the Latvian capital Riga has been described as "murder", by the country's president Andris Berzins. It is the deadliest disaster in Latvia since it regained independence in 1991(Gusta..., 2015). This accident showed a many problems, what exist in Latvia Civil defense system. In the article on identified shortcomings, the authors offer opportunities to improve the CD system.

\section{ACTUALITY}

Humanity and nature have come to a strong contradiction in the situation when accidents are considered as a routine case, mentioning the "human factor" as one of the causes of accidents in the assessment of circumstances. The "human factor" refers to all serious accidents that could have caused or caused a disaster caused through improper performance of human duties or engineer mistakes when designing technical devices, units etc. (Khoruzhenko.., 2010). Thus, the term "Human Factor" obtained a negative explanation in the analysis of many negative events and accidents. Man-made disasters, as well as daily activities related to the storage, production or transportation harmful substances in the event of an accident, industrial or transportation accident, adversely and irreparably affect the surrounding human and natural environment.

Copyright (C) 2017 The Authors. Published by Aleksandras Stulginskis University. This is an open-access article distributed under the terms of the Creative Commons Attribution License (CC-BY 4.0), which permits unrestricted use, distribution, and reproduction in any medium, provided the original author and source are credited. 
Based on the foregoing, it can be concluded that natural disasters ultimately result from man-made mistakes because protective measures often are not planned according to the threat or are not planned at the appropriate level of safety. By carrying out the safety and security measures in line with the threat level, it is possible to achieve a positive environmental safety effect that would reduce the risk and result in not occurring or occurring at minimum level the economic, social etc. damages to humans and society. One solution for locations where it is not possible to eliminate the threat by the existing technical means, is moving people for living in safe places.

Occurrence of a technogenic disaster usually threatens the surrounding nature and environment as well as the human life and health, depending on the amount and hazard of the released substance. Worldwide practice suggests that companies manufacturing hazardous substances and technology are often built close to residential areas and are therefore capable to cause significant damage to human life and health. In turn, these hazardous factors create a reasonable fear among local population, as a result of which public pressure on the state and local government institutions grows because residents do not want to live besides such enterprises.

This situation is also topical in the city of Riga, transportation of hazardous substances is carried out using railway and motorway networks that cross the entire city with densely populated areas, as well as one of the additional factors of increasing danger is the Freeport of Riga infrastructure that serves the inbound vessels. The increase of dangerous goods at the Freeport of Riga provides additional jobs for the population, investments in infrastructure, taxes, but together with positive economic development trends, the probability of the origin of possible negative factors and accidents is also increasing. In such situation, it is necessary to clearly understand whether Riga operative services and officials involved in the accident combat will be able to make the right decisions and quickly reduce the possible harmful consequences. Thus, at the beginning it is necessary to look at the current safety system of the Latvian state and its capital city and what regulatory enactments regulate it.

\section{DESCRIPTION OF STATE CIVIL DEFENCE SYSTEM}

Current protection of Latvian population, infrastructure, national economy facilities against disasters and their threats is carried out by the State Civil Defence system including the management institutions of several levels.

The competence and responsibilities of Latvian state and local government institutions are defined in the Civil Defense and Disaster Management Law (hereinafter - CAKPL), which entered into force on 01 October 2016, as well as in the National CD Plan, which is annually elaborated by the State Fire-Fighting and Rescue Service - SUGG) subordinated to the Ministry of the Interior, the elaboration being approved by the Cabinet of Ministers (hereinafter referred to as CM). In general, more regulatory enactments have been developed in Latvia, providing for the management of non-standard hazardous situations, each of them individually providing for actions and responsibilities of the involved national authorities. Currently, the State has adopted such mechanisms for the management of dangerous situations, the activities of which are regulated by specific laws, such as the CAKPL, the Emergency Situation and State of Exception Law (hereinafter - ASIS), the Mobilization Law (hereinafter - ML), the National Security Law (hereinafter - NDL). The Cabinet of Ministers regulations subordinated to the above-mentioned laws provide the individual algorithms of action for the involved state and local government institutions, legal and natural persons. Activity of facilities engaged in the production, transportation, transshipment or handling of hazardous substances is regulated and imposed with certain requirements by laws such as the Chemicals Law, the Pollution Law etc.

According to CAKPL, the CD is a complex of organizational, engineering, economic, financial, social, educational and scientific measures implemented by state and local government institutions and the society in order to ensure the safety of people, environment and property as well as to implement appropriate actions in the event of a disaster or disaster threats (Civil..., 2016).

The National Security Concept is a document prepared based on the national threat analysis, which sets out the strategic principles for the prevention of national threats, priorities and measures to be taken into account when developing new policy planning documents, laws and national security action plans (National ..., 2008).

The NDL defines that national security (hereinafter - NS) is a situation, achieved as a result of consolidated, targeted measures implemented by the state and society, with guaranteed independence of the state, its constitutional structure and territorial integrity, perspective free development, welfare and stability of society (National..., 2000).

The main tasks of the NS system are: timely anticipation and elimination of internal and external threats, public security and its democratic development; working out a unified systemic NS policy of institutions implementing the state power and management, and coordinated and purposeful fulfillment at all state administration levels of its legal, economic, social, military, security and other measures; provision of effective management to overcome the state threat situations (National..., 2000).

It should be noted that the main task of the NDL as well as of the CAKPL is to overcome the threat, to plan resources for its management, and in accordance with the NS concept the nationwide disasters (storm, heavy rain, heavy snowfall, earthquakes, large-scale floods, widespread or increased danger fires, leaks of hazardous substances, industrial breakdowns, dangerous infectious diseases, social disturbances etc.) overcoming issues shall be solved within the CD system framework, thus identifying these risks and threats within the State CD Plan (National security concept,2008).

The purpose of the ML is to establish the legal and organizational foundations for the preparation and implementation of mobilization of the National Armed Forces and the national CD system, the responsibilities and liability of state and local government institutions, private legal entities as well as individuals in mobilizing issues. 
The mobilization involves the National Armed Forces, the national CD system and national economy (The Mobilization..., 2002).

It should be stated that the ML lays down legal and organizational measures in case of national threats, which are a part of the CD system.

The purpose of the ASIS law is to ensure national security in the event of a national threat, the law defines the concept of the state of exception that is a special legal regime, during which the CM has the right to restrict the rights and freedoms of state administration and local government institutions, natural and legal persons, and impose them with additional responsibilities. The state of exception may be announced in case of such national threat that is related to a disaster, its threat or endangered critical infrastructure if there is a serious threat to the safety of the state, society, environment, economic security or human health and life (Emergency..., 2013).

In general, the common system of the NS regulatory enactments is reflected in Figure 1, which demonstrates that the measures envisaged by all the above laws and overlapping between themselves are important for the functioning of the common national security system. For example, the CAKPL provides for the population catering activities while the method of food distribution and content thereof are determined by the ML based the CM Regulation No. 585 of 28.08.2015 "Regulations on the provision of population with food in case of national threat" (hereinafter referred to as $\mathrm{CM}-585)$.

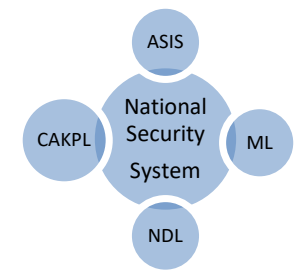

Figure 1. Latvian Nacional security system (Source: by the author)

Fulfillment of some of the measures envisaged by the mentioned laws is controlled by the responsible institutions, such as the SFRS, the Security Police, the Ministry of Defence, the State Environmental Service (hereinafter - the VVD), the Consumer Rights Protection Center, the responsible authorities established by each municipality, for example in Riga - the Housing and Environment Department, as well as the Riga Municipal Police (hereinafter - RPP), but no control is provided over the observance of many measures, therefore the execution on the part of the responsible institutions is at very low level. Due to lack of control, the ML based the CM Regulation No. 966 of 20.12.2005 "On the Procedure and Financing for the Establishment of Mobilizable Civil Defense Formations" are ignored by the Ministry of Interior (hereinafter referred to as the MI). Clause 4.2 of this Regulation prescribes the creation of municipality formations in the regions and republican status towns, which, according to mobilization requests from the MI, are formed by municipalities. The required number and tasks of the formations are determined by the MI. Within the framework of preventive measures, this event is very important since only the creation of a request and the establishment of the formation tasks can ensure the preparation of a highly qualified mobilizable CD personnel capable of acting in case of threat, but such request from the MI, for example in Riga, has never been submitted, therefore it can be concluded that the usefulness of the planned measures is not assessed by the MI, thus creating an entropy in the system.

It can be concluded that the CD system is an integral part of the common NS system and practically cannot work separately, but only along with the measures provided by the ASIS, ML, NDL. In the event of a disaster, the state of exception is usually announced, but in the event of a war or mass disorders the mobilization and the state of exception are announced, thus the probability of operation of the $\mathrm{CD}$ system alone is considered to be rather low since it cannot provide a full complex of protection and safety measures.

When managing a disaster, the local government council, based on the CD Commission decision, shall have the right to initiate that the Prime Minister overtakes the coordination of the local scale disaster management. The Prime Minister is the Head of the Crisis Management Council, its members being the following ministers: defence, foreign affairs, economics, finance, interior, justice, health, communication, environment protection and regional development. (Crisis.., 2016). An autonomous function of the Crisis Management Council is to coordinate the collaboration between the state and local government institutions in issues associated with the national threat preventive and combating measures as well as its consequences liquidation measures, as well as when necessary to coordinate the civil and military collaboration in the prevention and overcoming of the national threat. (Crisis.., 2016). Work of the Crisis Management Council is ensured by the Crisis Management Council Secretariat, which within the framework of its competence provides a purposeful and permanent collaboration of responsible institutions and support for the Crisis Management Council. Head of the Crisis Management Council Secretariat is the Head of the SFRS. In order to provide the Crisis Management Council with information about the national threat 24 hours per day, 7 days per week, the Unified Emergency Telephone Number 112 operates also as a coordination centre.

\section{CIVIL DEFENCE MEASURES IN RIGA AND NECESSARY IMPOVEMENTS}

The law "On local governments" imposes on the local governments a liability to participate in provision of the CD measures, which is an autonomous function of every local government. Riga CD plan is developed for fulfilment of Riga municipality's autonomous functions and implementation of preventive measures with the objective not to allow or mitigate possible adverse consequences for population, infrastructure, environment, which can occur upon incident, accident or 
breakdown. The effective Riga CD plan was developed by the SFRS workers together specialists of the Riga Municipal Police (hereinafter referred to as RPP). Responsibilities and functions of Riga CD are transferred to RPP, which is specified in RPP Provisions. Based on these Provisions, a special structural unit is established in RPP: Water S.A.R. and Civil Defence Department, of which staff members carry out the imposed measures of Riga CD. Riga CD plan provides preventive, preparative, responsive and consequence liquidation emergency measures to be taken within Riga administrative territory. Riga CD plan consists of information. of which composition is specified in the CM Regulation No. 423 of 26.06.2007 "Civil defence plan of local government, merchant and institution: structure, procedure of development and approval".

With the objective to efficiently implement measures for management of possible disasters, the CD commission is formed in the Riga Municipality. Membership, rights and tasks of the Municipal CD Commission are governed by the CM Regulation No. 1078 of 22.09.2009 "Model Provisions of Municipal Civil Defence Commission”. Work of Riga CD Commission is regulated by the Commission Provisions approved by the order of the Riga Council Chairman and specifying its liabilities and tasks as well as establishing the commission structure. Riga CD Commission consists of the commission chairman, two deputies, three permanent commission members and seventeen visiting commission members being the specialists of various state and municipal institutions.

In 2014, the Riga Council Chairman approved Riga CD plan developed by the SFRS together with RPP staff members. The last time it was elaborated and supplemented in 2017 with a new information as well as updated. The CD plan is reviewed not rarer than once a year or within three months of the time when changes took place, amendments were made to the regulatory enactments or circumstances have occurred, which could affect the implementation of measures included in the plan. Upon occurrence of incident, accident or breakdown as well as existing threat, the CD mechanism is activated. Decision on calling the commission is taken by the commission chairman or, in the absence thereof, by one of his deputies. Notification of the commission members is carried out by the secretary who is the administrative officer of the Riga Council Security, Public Order and Corruption Prevention Committee.

In order to immediately ensure the response in case of breakdown, it is necessary to plan the involvement of operative resources at the place of accident. Necessary resources for performance of municipal CD tasks and planning in Riga are dealt with by RPP that has collaboration agreements with enterprises possessing a specific machinery or other necessary resources. The main role in provision and involvement of resources is played by the SFRS since it deals with rescue works and general national policy in the $\mathrm{CD}$ field.

To carry out CD tasks specified in Riga in case of disaster or threat thereof, it is necessary to: ensure the evacuation of inhabitants from territories affected or endangered by disaster as well as the accounting of these inhabitants, their temporary accommodation, catering and social care, also within own possibilities to provide with adequate working and living conditions the officials of state and municipal institutions, legal entities and natural persons involved in disaster management (Civil..., 2016). Limits of possibilities of each local government may differ depending on the number of inhabitants and available provision. These limit criteria are not specified anywhere and make this issue a free will of the local government depending on each local government's policy in the field of CD.

Upon occurrence of the SE, it is very important to possibly faster start the liquidation of breakdown thus saving people and values from destruction risks and inhabitants from injuries; therefore it is important that the personnel involved in the response is adequately trained and capable of carrying out works in most unpredictable situation. Adequately trained and qualified personnel is capable to provide rescue works on high professional level, not falling into panic and not becoming the victims themselves. It is very important for the affected people to be aware that assistance comes and that every person will be provided with the necessary support from the public authorities as well as from the organizations involved.

In order to systematically and wholistically solve CD-related tasks in Riga, a collaboration agreement was concluded in 2016 with the Riga Council Education and Culture Department with the objective to provide in Riga administrative territory a temporary accommodation of evacuated inhabitants in cases of possible disasters or their threats, anticipating to provide place for 26,820 inhabitants (Riga Civil..., 2014).. In collaboration with the state and municipal institutions the RPP permanently participated in planning of the $\mathrm{CD}$ training and its performance in Riga administrative territory, of which purpose is to check the procedure and measures specified in the CD plans of the facilities, beyond these plans, as well as to control how the facilities provide the collaboration with rescue, emergency services and other state and municipal institutions, carrying out the disaster management measures in case of undesirable events or industrial breakdowns.

Abovementioned measures only provide overcoming local SE cases and partial defence solution; it is necessary to plan the collaborative measures with other local governments with the objective of short-term and long-term accommodation and provision of inhabitants. At present time in Riga the collaboration agreements are not concluded with other local governments on provision of inhabitants' accommodation and catering services.

Now we will review the costs of the CD system for Riga Municipality in order to ensure the existence of inhabitants in case of the SE and on the background of the reviewed situation will try to find an answer whether the municipality is capable to perform responsibilities and tasks imposed by the CAKPL without the support of the whole country.

As the first measure that the municipality must ensure, we review the catering of suffered inhabitants.

Average complex dinner in Riga costs about 3 EUR, which is the average price in urban eating houses; in situation when the inhabitants must be fed three times a day this price should be multiplied by 3 . The outcome of this arithmetic procedure gives the daily price equal to 9 EUR, which includes breakfast, dinner and supper. According to data available in Riga CD plan, 698,086 inhabitants reside in Riga, in case of full city evacuation it will be necessary to ensure the catering of these inhabitants or their supply with food products. Making arithmetic calculation 698086*9EUR =6,282,774 EUR, we obtain this amount necessary to feed all Riga inhabitants during one day. The evacuation measures usually take more than one day, therefore at minimum estimates several evacuation days should be reckoned with. Such situation will 
require $6282774 * 5$ (days $)=31,413,870$ EUR and this amount should be reckoned with in Riga in order to feed the evacuated inhabitants during five consecutive days on condition that enterprises will be available, which will be capable to feed such number of people. To feed such number of people, the catering enterprise should hold a stock of food, which only can be ensured by large enough enterprises that are planning the food reserves. In current situation, enterprises in order to ensure fresh food try not to maintain stocks and warehouses but purchase necessary amount of raw products for a certain minimal period, the system is working according to the logistic principle. Upon occurrence of the SE situation, it is necessary to take into consideration that the first of the measures suffering in case of any disaster is associated with the infrastructure facilities, therefore cannot rely upon the logistic supply measures.

In accordance with requirements of the Law on Social Services and Social Assistance, catering services for the suffered people should be provided by the local government, the law defines the term the basic needs, including: food, clothes, dwelling, health care, mandatory education.

The objective of social assistance is to render material support for needy, low-income and crisis situation families (persons) in order to ensure their basic needs and promote the collaboration of employable persons in improvement of own situation (Law on Social..., 2002).

The crisis is defined as a state where a person perceives an event as unbearable difficulties that exceed his ability to overcome them (G. Belkin...,1984).

Evacuating Riga inhabitants from their place of residence in the event of a disaster or threat thereof will affect their ability to meet their basic needs and deprive of the ability to deal with it. Based on the above said, provision of the abovementioned measures in Riga must be carried out by the Social Service established by the Welfare Department. Currently, Riga Welfare Department does not perform such functions and has not concluded agreements on provision of citizens; it is clear that Riga is not ready to overcome the possible catastrophic hazards and provide food for the population. The nutrition norms for the population groups also differ and are standardized, it is provided by the CM 585. It is also important to emphasize that the catering of inhabitants according to the should be carried out by the municipality, but the planning and coordination of deferred food supply in accordance with the CM 585 is ensured by the Ministry of Agriculture in cooperation with the Ministry of Regional Development and Local Government and local governments. The Regulation stipulates that in the event of national threat the municipality of a national importance town shall: develop a procedure for ensuring food delivery to the population in the administrative territory of the municipality; inform the inhabitants via the media about food distribution and issuing points; approves the heads of food issuing points and the number of staff required to organize food issue at the point; organize the accounting of issued foodstuffs; if necessary, arrange transport for the delivery of food to the inhabitants (G. Belkin...,1984). Based on the abovementioned, it is necessary to establish a procedure in Riga for ensuring the delivery of food to the inhabitants in the administrative territory of the municipality only in the case of national threat while for preventive purposes this procedure shall not be developed since it reduces the capacity of Riga CD system if the threat (disaster, SE) is sudden and there is no time to prepare and develop this kind of procedure, it must be developed in advance.

The author of the study, carrying out the system analysis, did not find such planning documents and the established system in Latvia, which suggests that such system has not been established, there is also no clear information about the catering of inhabitants and the development of food distribution procedures in Riga CD plan.

As the second measure to be provided by the municipality, we review the relocation of the affected inhabitants from the endangered places to the place of evacuation accommodation. It is extremely important to plan the transport provision and the resulting costs to ensure the CD activities. According to data of Riga CD plan, vehicles of Riga company LLC Rigas Satiksme are planned to be used for evacuation of the population. In total, the company has 406 buses of different capacities, 230 trolleybuses and 178 trams (Riga Civil..., 2014). Since use of electric transport outside urban networks is not possible or possible for a short time, therefore, we will consider the provision of evacuation measures using the bus transport. At the probability that some people have their own vehicles, there is no need to move all the people using buses, therefore the number of people can be divided by $2: 698,086 / 2=349,043$ inhabitants who need to be relocated using public transport. On average, one bus can accommodate 70 passengers, thus mobilizing $100 \%$ of buses available in Riga (removing them from routes), it is possible to move 28,420 people at a time. The average bus service cost per hour is 50 EUR, so it is possible to expect one hour's operating costs as $406 * 50=20,300$ EUR per hour, or 484,200 EUR per 24 hours, being the cost of population relocation to the place of evacuation during $24 \mathrm{~h}$, provided there are bus drivers who can change each other when transporting people from one place to another. Depending on places of evacuation, there is also a difference in the number of trips and the number of people that can be transported by one bus during $24 \mathrm{~h}$ period. In order to plan an uninterrupted transfer of all Riga inhabitants, the number of people needs to be divided by the number of people transportable by available vehicles at a time: $698068 / 28420=24.56$ hours can take evacuation of inhabitants provided the buses will be used without interruptions and at a distance taking up to 30 minutes from the evacuation site, which means approximately $15 \mathrm{~km}$ distance from the evacuation gathering place and back to the starting point within 1 hour. For 24.56 hours of buses use, it is necessary to provide for the following costs to be paid to the bus fleet: $20,300 E U R * 24.56=498,568$ EUR.

As the second measure to be provided by the municipality, we review the accommodation of the affected people through hotel services. In total, it is necessary to accommodate 698,086 inhabitants, which is impossible summing up the capacities of all hotels in Latvia, therefore it is necessary to use the public housing facilities of the state, local governments and institutions to accommodate the affected inhabitants. On average, such costs can amount to about EUR 2 per person per $24 \mathrm{~h}$ - provision of electricity, water, drainage, which would cost in total $698,086 * 2=1,396,172$ EUR per $24 \mathrm{~h}$. 
Thus, in order to maintain and take all Riga inhabitants to the place of evacuation, the following amount of money per day is required: EUR 6,282,774 (catering) + 1,396,172 EUR (accommodation) + 498,568 EUR (transport costs) $=$ EUR $8,177,514$ for the first day of the SE. For every next day, it will be necessary to spend 7,678,946 EUR, that is, the total expenses of the Riga Municipality for 5 days of population accommodation will amount to 8,177,514 EUR for the first day, from the second to the fourth day $(7,678,946 \mathrm{EUR} * 4$ days $)=30,715,784 \mathrm{EUR}$, together for 5-day period - 38,893,298 EUR.

Riga budget for 2017: municipality's revenues planned in the amount of 865,715,142 EUR and expenses anticipated 894,541,599 EUR, thus making the budget deficit 28,826,457 EUR.

When planning Riga budget for the CD measures for at least 5 days, it is necessary to provide at least 38,893,298 EUR, and then can count on the international assistance that in case of such scale disaster should be requested by the Latvian government. International assistance includes humanitarian aid, also food products.

In order to ensure that the CD measures discussed above, the municipality needs to plan substantial funds in order to be able to ensure CD tasks specified in the CAKPL, which at present time are not planned.

Examining the tasks and responsibilities of the municipality in the field of $\mathrm{CD}$, it is found that Riga is not capable at present to ensure the efficient operation of the $\mathrm{CD}$ system at its own level, it requires the state participation and planning of the support system,

In general, the introduction of a new system established by the CAKPL is accompanied by a number of specific characteristic problems as well as system problems related to the implementation at national and municipal level.

\section{CONCLUSIONS}

Existence of various threats requires a qualitative development of laws and the CM regulations, organization and maintenance of professional services in the country, the overall task of which is to efficiently operate the CD system. The presence of potential risks also determines the responsibilities of the municipality for protecting civilians from potential risks, but it is necessary to consistently separate the scope of liability according to the policy of incomes and expenses. Efficient system operation is achieved by realizing the joint national and municipal security system development plans by developing and implementing the theoretical and practical training of officials and population, participating in joint exercises with the forces of other state institutions, implementing in full extent the provided management and protection regulatory enactments and plans governing the $\mathrm{CD}$.

Weakly expressed coordination of the national CD system, which in accordance with the CAKPL is managed by the Ministry of the Interior, allows entropy on the part of organizations involved in the CD system, which due to the system inefficiency and incapability fail to comply with the adopted regulatory enactments. Despite the fact that various activities and projects related to the development of the CD system have already been implemented or are currently taking place in the country, they are generally not coordinated and tend to be controversial. At national level, there is a lack of the CD system process manager who will be responsible for the system as a whole. The situation and the problems in general are not systematically evaluated, development of relevant political and regulatory enactments and prevention of the identified problems are not initiated. In the article the necessary means for the functioning of the CD system in Riga city.

The purpose of the national security system is to find a solution for adapting, modernizing and optimizing the functionality of the CD system, the interconnection of institutions involved in the system operation, providing to create a centralized approach to security issues nationwide and in Riga, planning all resources available in the country for the CD system functioning. This solution will open up wider opportunities for use of communication and resources among institutions, inhabitants and entrepreneurs, intending to improve not only the quality of cooperation but also its efficiency and overcome possible SE.

\section{REFERENCES}

1. Belkin G.S. 1984. Introduction to counseling 2 rd ed.. W.C. Brown. Pennsylvania State University.

2. Civil Defense and Disaster Management Law. 2016. "Latvijas Vēstnesis”, 100 (5672). [In Latvian].

3. Crisis Management Board [Online]. Valsts ugunsdzēsības un glābšanas dienesta mājas lapa. Available at: http://vugd.gov.lv/lat/par_vugd/darbibas_sferas/3153-krizes-vadibas-padomes-sekretariats (Accessed: 11/11/2016). [In Latvian]

4. Emergency and Exceptional Situation Law. 2013. "Latvijas Vēstnesis", 61 (4867). [In Latvian]..

5. Gusta A. 2015. Tragedy in Zolitude - a lesson for contemporary society. Proceeding of $7^{\text {th }}$ International Scientific Conference "Rural Development 2015". Aleksandras Stulginskis University, Lithuania, pp. 1-6. http://doi.org/10.15544/RD.2015.017

6. Khoruzhenko. A. 2014. Bases of the Homogenesis's Theory of Emergency Situations. Civil Security Technology, Vol, 11, Nr.1(39), pp. 30 [In Russian].

7. Krūzs.K. 2003. Use of natural and secondary resources. SIA "Izglītības soḷi". Riga. [In Latvian]..

8. National Security Concept. 2008. "Latvijas Vēstnesis", Nr. 167 (3951). [In Latvian]..

9. National Security Law. 2000. "Latvijas Vēstnesis”, 473/476. [In Latvian]..

10. Riga City Civil Defense Plan. 2014. pp. 33.-38.pp. [In Latvian].

11. Law on Social Services and Social Assistance. 2002. "Latvijas Vèstnesis", 168 (2743) [In Latvian].

12. The Mobilization Law. 2002. "Latvijas Vēstnesis”, 91 (2666). [In Latvian] 